\title{
BIOLOGICAL CONTROL OF POTATO BLACK SCURF BY RHIZOSPHERE ASSOCIATED BACTERIA
}

\author{
${ }^{1}$ Mohsin Tariq, ${ }^{1}$ Sumera Yasmin, ${ }^{*}$ Fauzia Y. Hafeez \\ ${ }^{1}$ National Institute for Biotechnology and Genetic Engineering (NIBGE), P.O. Box 577, Jhang Road, Faisalabad 3800-Pakistan; \\ ${ }^{* 2}$ Department of Biosciences, COMSATS Institute of Information Technology Chak Shahzad Campus, Park road, Islamabad, \\ Pakistan.
}

Submitted: April 27, 2009; Returned to authors for corrections: September 03, 2009; Approved: October 06, 2009.

\begin{abstract}
The present work was carried out to study the potential of plant rhizosphere associated bacteria for the biocontrol of potato black scurf disease caused by Rhizoctonia solani Khun AG-3. A total of twenty-eight bacteria isolated from diseased and healthy potato plants grown in the soil of Naran and Faisalabad, Pakistan were evaluated for their antagonistic potential. Nine bacterial strains were found to be antagonistic in vitro, reduced the fungal growth and caused the lysis of sclerotia of $R$. solani in dual culture assay as well as in extracellular metabolite efficacy test. The selected antagonistic strains were further tested for the production and efficacy of volatile and diffusible antibiotics, lytic enzymes and siderophores against $R$. solani. Selected antagonistic bacteria were also characterized for growth promoting attributes i.e., phosphate solubilization, nitrogen fixation and indole acetic acid production. Biocontrol efficacy and percent yield increase by these antagonists was estimated in greenhouse experiment. Statistical analysis showed that two Pseudomonas spp. StT2 and StS3 were the most effective with 65.1 and 73.9 percent biocontrol efficacy, as well as 87.3 and 98.3 percent yield increase, respectively. Potential antagonistic bacterial strain StS3 showed maximum homology to Pseudomonas sp. as determined by 16S rRNA gene sequencing. These results suggest that bacterial isolates StS3 and StT2 have excellent potential to be used as effective biocontrol agents promoting plant growth with reduced disease incidence.
\end{abstract}

Key words: Biological control; Potato black scurf; Rhizobacteria; Pseudomonas; Rhizoctonia solani.

\section{INTRODUCTION}

Among biotic stresses, plant pathogenic microorganisms are the serious threat to crop production and ecosystem stability $(41,44)$. Different methods have been used to control plant pathogens, being the most used cultural practices, resistant cultivars, chemical and biological control. Biological control is a natural and specific way to control pathogens and enhance crop yield by growth promoting attributes of environment friendly microorganisms (20. 34, 38). This method has been developed successfully during the last few years. It is based on the reduction of inoculum or of pathogenic activity due to the natural presence of one or more organisms, through the management of the environment, the host or antagonists (3).

R. solani is one of the most prevalent and important soil

*Corresponding Author. Mailing address: Deptt. of Biosciences, COMSATS Institute of Information Technology Chak Shahzad Campus, Park road, Islamabad, Pakistan.; Tel: +92-42-92-051-4340857 Cell +92-300-6602614.; E-mail: fauzia@ comsats.edu.pk fauzia_y@yahoo.com 
borne fungal pathogen causing destruction of a wide range of economically important crops such as rice, wheat, tomato, potato etc. $(14,27)$. Black scurf of potato (Solanum tuberosum L.) is a soil and seed borne disease, caused by R. solani Kuhn AG-3. Black spots of fungus (sclerotia) about $1 \mathrm{~mm}$ to $10 \mathrm{~mm}$ appears on the potato surface. These sclerotia, also known as black scurf, are difficult to remove by washing and brushing (49). The black scurf stage may often produces tubers that are misshapen, cracked, and discolored by the presence of sclerotia on the tuber surface. Black scurf is found in most of the potato growing areas throughout the world. It can be very severe in eastern Canada and Maine (10). Black scurf is widely spread in Pakistan, especially in northern areas of Swat, Kaghan, Dir, Hunza Valley etc. A few areas of Punjab are also affected.

Fungi from Trichoderma genus are among the biological control agents of $R$. solani $(1,23)$. On the other hand, bacteria belonging to genus Pseudomonas and Bacillus have also been used in bioantagonism $(2,12)$.

The present research work was carried out to study the potential of rhizobacteria to control potato black scurf diseases and thus increase crop yield. To control plant diseases, bacteria have some weapons in their extracellular metabolites i.e., siderophores, antibiotics, lytic enzymes etc. $(8,13)$. Keeping in view the above facts, our objective was to isolate and select antagonistic bacterial strains that could control $R$. solani both in vitro and in vivo and to study the mechanisms of antagonism.

\section{MATERIALS AND METHODS}

\section{Isolation of Rhizoctonia solani and growth condition}

Black scurf infected tubers of potato (Solanum tuberosum L.) cv. Cardinal were surface sterilized by $0.1 \%$ mercuric chloride $\left(\mathrm{HgCl}_{2}\right)$ for two minutes and extensively washed with sterile distilled water (SDW). Clot like black spot on the surface of potato were peeled and placed on petri plates containing potato-dextrose-agar (PDA) and incubated at $25 \pm 2$ ${ }^{\circ} \mathrm{C}$ for $48 \mathrm{~h}$. Grown fungal culture was purified by subculturing and identified using stereomicroscope after staining with trypan blue. Pure culture of $R$. solani was stored at $5^{\circ} \mathrm{C}$ in culture tubes and petri plates containing PDA (18). All isolation steps were performed under aseptic conditions. Five $\mathrm{mm}^{2}$ mycelial disc from a 5 days old culture of $R$. solani on PDA was placed in $1000 \mathrm{~mL}$ flask containing $500 \mathrm{~mL}$ of potato-dextrose broth (PDB) and grown at $25 \pm 2^{\circ} \mathrm{C}$ for 10 days. The colonies of fungi were developed and produced many sclerotia.

\section{Determination of virulence in $\boldsymbol{R}$. solani}

Virulence of $R$. solani was first tested in a greenhouse. For pathogenicity test, approximately $1 \mathrm{~mL}$ of fungal inoculum (mycelium and sclerotia) was dropped at the injured stem of one month old potato cv. Cardinal plants grown in pots containing $10 \mathrm{~kg}$ soil. SDW was used as control. The plants were observed for symptoms of black scurf i.e., stem lesions, leaf chlorosis and black spots on tuber skin at the time of harvest.

In vitro pathogenicity test was also performed on leaves, stem and tuber of potato $\mathrm{cv}$. Cardinal in petri plates under aseptic conditions. $1 \mathrm{~mL}$ of 10 days old broth culture of $R$. solani was used to infect the leaves/ stem/ tuber placed in separate petri plates taken from the 30 days old plant. PDB broth was used as controls. All petri plates were incubated at $25 \pm 2{ }^{\circ} \mathrm{C}$ for 5 days. The samples were supplemented daily with $1 \mathrm{~mL}$ SDW to avoid dehydration. The plant samples were observed for symptoms of black scurf i.e., stem lesions, leaf chlorosis and black spots on tuber skin (18).

\section{Isolation of bacteria and growth condition}

Bacteria were isolated from soil, rhizosphere, roots and tubers of healthy and diseased potato plants collected from Naran and Faisalabad, Pakistan. One gram of soil/ rhizospheric soil/ crushed roots/ crushed tuber was homogenized in $20 \mathrm{~mL}$ test tube containing $9 \mathrm{~mL}$ saline $(0.85 \% \mathrm{NaCl})$ separately. The suspension was vortexed and dilutions were prepared up to $10^{-7}$. $0.1 \mathrm{~mL}$ of each dilution was spread on Luria Bertani medium plates. The plates were incubated at $25 \pm 2{ }^{\circ} \mathrm{C}$ until colony development was observed. A large number of bacterial colonies were developed. Morphologically different colonies were selected and purified by sub-culturing (32). Pure cultures 
were subjected to growth studies.

\section{Primary selection of antagonists}

Antagonism of all the 28 rhizosphere associated bacterial isolates was evaluated in two major in vitro tests: dual cultures assay and extracellular metabolites efficacy test against $R$. solani. Potential antagonists were selected for further studies.

Dual cultures assay: One 5- $\mathrm{mm}^{2}$ disk of a pure culture of $R$. solani was placed at the center of a petri dish containing PDA. A circular line, made with a 4-cm diameter Petri dish dipped in a bacterial suspension of $\left(2 \times 10^{9} \mathrm{cfu} / \mathrm{mL}\right)$, was placed surrounding the fungal inoculum. Plates were incubated at $25 \pm 2{ }^{\circ} \mathrm{C}$ for $72 \mathrm{~h}$ and growth diameter of the pathogen (fungal growth) was measured and compared to control growth where the bacterial suspension was replaced with LB broth. Trichoderma harzianum (obtained from $1^{\text {st }}$ Fungal culture bank of Pakistan, Department of Mycology \& Plant Pathology, Punjab University Lahore, University of Pakistan) used instead of bacterial suspension against $R$. solani was included as positive control. Results were expressed as means of radii of fungal growth $(\mathrm{mm})$ and $\%$ inhibition of fungal growth of the corresponding $R$. solani isolate in the presence of any of the bacterial isolates $(5,27)$. Percent inhibition was calculated using the following formula:

$\%$ inhibition $=[1-($ Treatment growth/Control growth $)] \times 100$

Extracellular metabolites efficacy test: These tests were performed in $250 \mathrm{~mL}$ flasks containing $100 \mathrm{~mL}$ of sterile $\mathrm{LB}$ broth. Bacterial growth was maintained at $2 \times 10^{9} \mathrm{cfu} / \mathrm{mL}$. T. harzianum (positive control) was inoculated in PDA broth flask. T. harzianum and bacterial cultures were pelleted by centrifugation at $6,000 \mathrm{rpm}$ at $4^{\circ} \mathrm{C}$ for $12 \mathrm{~min}$. The supernatants were sterilized with $0.22 \mu \mathrm{m}$ filter. Culture filtrate $25 \%(\mathrm{v} / \mathrm{v})$ was mixed with PDA and a $5 \mathrm{~mm}^{2}$ disk of four days old pure culture of $R$. solani was placed at the center of petri dish. These plates were incubated at $25 \pm 2{ }^{\circ} \mathrm{C}$ for $72 \mathrm{~h}$. Growth diameter of the pathogen (fungal growth) was measured and compared to control growth where the bacterial extracellular metabolites were replaced with LB broth. Results were expressed as means of radii of fungal growth $(\mathrm{mm})$ and \% inhibition of growth of $R$. solani in the presence and absence of any bioantagonistic bacterial isolate (19).

\section{Tentative identification of antagonists}

Antagonistic bacterial strains were tentatively identified by gram staining (47) and light microscopy (Table 1). Fluorescent pseudomonads were identified on King's B plates (46). These bacterial isolates were stored at $5{ }^{\circ} \mathrm{C}$ in slants containing King's B agar, and in flasks containing TSB (Tryptone Soy Broth) with $20 \%$ glycerol for storage at $-21{ }^{\circ} \mathrm{C}$ (40).

\section{Mechanisms involved in antagonism}

Volatile antibiotics: $100 \mu \mathrm{L}$ of a bioantagonistic bacterial suspension $\left(2 \times 10^{9} \mathrm{cfu} / \mathrm{mL}\right)$ were placed at the center of one half petri dish containing King B medium. T. harzianum used instead of bacterial suspension used as positive control. A 5$\mathrm{mm}^{2}$ disk of a four days old pure culture of $R$. solani was placed at the center of another Petri dish containing PDA. Both half plates were placed face to face preventing any physical contact between the pathogen and the bacterial culture. Plates were sealed to isolate the inside atmosphere and to prevent loss of volatiles formed. Plates were incubated at $25 \pm 2{ }^{\circ} \mathrm{C}$ for $48 \mathrm{~h}$ and the growth of the pathogen was measured and compared to control where the bacterial suspension was replaced with LB broth. Results were expressed as means of \% inhibition of the growth of $R$. solani in the presence and absence of any bacterial isolate (19).

Diffusible antibiotics: PDA plates covered with a cellophane membrane were inoculated in the center with 100 $\mu \mathrm{L}$ of a bioantagonistic bacterial suspension $\left(2 \times 10^{9} \mathrm{cfu} / \mathrm{mL}\right)$. T. harzianum used instead of bacterial suspension was taken as positive control. After incubation at $25 \pm 2{ }^{\circ} \mathrm{C}$ for $72 \mathrm{~h}$, the membrane with the grown bacterial isolate was removed, and 
the plate was inoculated in the middle with a $5-\mathrm{mm}^{2}$ disk of a pure culture of $R$. solani. Plates were further incubated at $25 \pm 2$ ${ }^{\circ} \mathrm{C}$ for $48 \mathrm{~h}$ and the growth of the pathogen was measured and compared with control where the bacterial suspension was replaced with LB broth. Results were expressed as means of \% inhibition of growth of $R$. solani in the presence and absence of any bioantagonistic bacterial isolate (27).

Siderophores: Siderophores production by the bacterial isolates was detected using the universal chrome azurol ' $\mathrm{S}$ ' (CAS) assay as described by Schwyn and Neillands (1987). CAS plates were spotted with single colony from overnight grown cultures and incubated at $25 \pm 2{ }^{\circ} \mathrm{C}$ for $72 \mathrm{~h}$ (Sharma and Johri, 2003; Nair et al., 2007). The amount of siderophore produced was measured as described by Rachid and Bensoltane (2005) Bacterial growth was estimated turbidimetrically at 600 $\mathrm{nm}$, the amount of siderophore secreted into the culture medium was determined by removing bacteria by centrifugation and measuring the absorbance of the supernatant at $400 \mathrm{~nm}$. Concentration was calculated using absorption maximum $(\lambda=400 \mathrm{~nm})$ and molar extinction coefficient $\varepsilon=$ 20000. (Table. 1).

Efficacy of siderophore for the uptake of $\mathrm{Fe}^{+3}$ and the effect of $\mathrm{Fe}^{+3}$ level of medium on antagonism was studied according to Pumarino (39), using $\mathrm{FeCl}_{3} \times 6 \mathrm{H}_{2} \mathrm{O}$ at 0, 5, 25 and $50 \mu \mathrm{M}$ concentrations added to King B agar medium. Dual culture assay was carried out using these modified KB plates.

Lytic enzymes: Bacteria were cultured either on plates with solid medium or in tubes with liquid medium after inoculation with $100 \mu \mathrm{L}$ of a bacterial suspension $\left(2 \times 10^{9}\right.$ $\mathrm{cfu} / \mathrm{mL}$ ). Media contained chitin as the sole carbon source. Development of bacteria was assessed through colony counting after incubation at $25 \pm 2{ }^{\circ} \mathrm{C}$ for $48 \mathrm{~h}$ of plates with solid medium or through measurement of absorbance at $600 \mathrm{~nm}$ after incubation of tubes with liquid medium at $25 \pm 2{ }^{\circ} \mathrm{C}$ for $48 \mathrm{~h}$. Concentrated supernatants from liquid cultures of each bacteria were analyzed for the presence of chitinase as described by Zaldivar et al. (51) and Perez et al. (35).
Protease production was tested by streaking each bacterial isolate on Skim Milk Agar (SMA) medium on the petri plates. The bacterial isolates that produced protease were identified by halo zone around the bacterial colony and were measured (6, 19).

\section{Growth promoting characteristics of antagonists}

Nitrogen fixation: Pure bacterial colonies were inoculated in to NFM semisolid enrichment medium in vials and incubated at $25 \pm 2{ }^{\circ} \mathrm{C}$ for $48 \mathrm{~h}$. Nitrogenase activity was measured as described by Yasmin et al. (2004). Acetylene $(10 \% \mathrm{v} / \mathrm{v})$ was injected to the vials. After incubation for 16 hours at room temperature, gas samples $(100 \mu \mathrm{L})$ were analyzed on a gas chromatograph (Thermoquest, Trace G.C, Model K, Rodono Milan, Italy) using a Porapak Q column and a $\mathrm{H}_{2}$-flame ionization detector (FID).

Indol acetic acid (IAA) production: For detection and quantification of IAA production by the bacterial isolates, cultures were grown in Okon's malate medium (30). Tryptophan (100 mg/ L) was added as the precursor of IAA. After one week of growth, qualitative estimation of IAA was performed by $\mathrm{Fe}-\mathrm{HClO}_{4}$ and $\mathrm{Fe}-\mathrm{H}_{2} \mathrm{SO}_{4}$ reagents. The ethyl acetate oxidation method was used for a quantitative estimation of IAA by HPLC using Turbochom software (Perkin Elmer USA) (17).

Phosphate solubilization: A single colony of bacterial culture grown on LB plate was streaked on to Pikovskia's plate containing tricalcium phosphate (37) and incubated at $25 \pm 2{ }^{\circ} \mathrm{C}$ for 7-10 days. The plates were observed for clear phosphate solubilization around colonies (14). Phosphate solubilization was quantified by Phospho-molybdate blue color method (28).

\section{Evaluation of antagonists in greenhouse}

To evaluate in vivo biocontrol potential of primarily selected antagonistic bacterial, sterilized soil was infested with $R$. solani. Ten days old $R$. solani in PD broth was diluted ten times and $50 \mathrm{~mL}$ inoculum of this fungus was mixed in $12 \mathrm{~kg}$ 
soil per pot. The experiment was conducted in completely randomized design (CRD) with three replicates and eleven treatments including two control treatments. There were nine treatments of antagonistic bacteria; T. harzianum grown in PDA was positive control whereas LB broth was used as negative control.

Potato cv. Cardinal tuber seeds having about five eyes (buds) were surface sterilized with $0.1 \%$ mercuric chloride, washed extensively with SDW and dipped in bacterial suspension $\left(2 \times 10^{9} \mathrm{cfu} / \mathrm{mL}\right)$ for three hours. One seed from each treatment was then sown in fungal infected soil in each pot. Plants were regularly watered after every three days. Second and third inoculum of antagonistic bacteria maintained at $2 \times 10^{9} \mathrm{cfu} / \mathrm{mL}$ was given to the plants after 25 and 50 days of germination ( $1 \mathrm{~mL} /$ plant). Plants were harvested after 110 days and the data was taken for parameters i.e., actual yield (kg) and disease incidence (6). Experiment was conducted in autumn growing season, from September to December.

The disease incidence was measured at the time of harvest by counting number of sclerotia at tuber skin. The results expressed as biocontrol efficacy, were calculated using the following formula $(15,16)$;

Biocontrol efficacy $=[($ Disease incidence of control- disease incidence of treatment) / Disease incidence of control] $\times 100$

Yield of potato tuber was also determined at the time of harvest. The results expressed as yield increase percentage were calculated using the following formula (16);

Yield increase $\%=[($ treatment yield - Control yield $) /$ Control

$$
\text { yield] } \times 100
$$

\section{Statistical analysis}

The Analysis of Variance for volatile \& diffusible antibiotics, disease incidence, biocontrol efficacy, yield and \% yield increase was calculated and mean comparisons were conducted using Duncan Multiple Range test at $P=0.05$. Standard Errors were also calculated (36). Statistical operations were performed on CoStat version 6.303 and MS Excel 2000.

\section{S rRNA gene amplification and sequencing}

Total genomic DNA of bacterial strain StS3 was isolated by the alkaline lysis method (26) with slight modifications. The primers used for amplification of full length 16S rRNA gene were universal primer P1 (forward primer, 5 CGGGATCCAGAGTTTGATCCTGGTCAGAACGAACGCT - 3`) and P6 (reverse primer, 5 CGGGATCCTACGGCTACCTTGTTACGACTTCACCCC 3), which correspond to E. coli positions 8-37 and 1479-1506, respectively and amplifies $1500 \mathrm{bp}$ fragment (45).

Each $25 \mu \mathrm{L}$ of reaction mixture contained $1 \mathrm{U}$ of Taq Polymerase (Promega), $2.5 \mu \mathrm{L}$ 10x PCR buffer, $2 \mu \mathrm{L} \mathrm{MgCl}_{2}$, and $1 \mu \mathrm{L}$ dNTPs $(2.5 \mathrm{mM}), 1 \mu \mathrm{L}$ of each primer $\left(100 \mathrm{ng} \mu \mathrm{L}^{-1}\right)$ and $1 \mu \mathrm{L}$ template DNA (12.5 $\left.\mathrm{ng} \mu \mathrm{L}^{-1}\right)$. Reaction mixture $(25$ $\mu \mathrm{L})$, prepared for $16 \mathrm{~S}$ rRNA gene amplification was initially denatured at $94{ }^{\circ} \mathrm{C}$ for 2 min followed by 25 cycles consisting of denaturation at $94{ }^{\circ} \mathrm{C}$ for $60 \mathrm{sec}$, primer annealing at $52{ }^{\circ} \mathrm{C}$ for $60 \mathrm{sec}$ and primer extension at $72{ }^{\circ} \mathrm{C}$ for $3 \mathrm{~min}$ and finally extension at $72{ }^{\circ} \mathrm{C}$ for $20 \mathrm{~min}$ in a thermal cycler.

The amplified 16S rRNA gene from most antagonistic strain StS3 was ligated in TA cloning vector pTZ57R/T (Fermentas). In case of pTZ57R/T vector, $30 \mu \mathrm{L}$ ligation reaction was prepared in sterile water with $1.5 \mu \mathrm{L}$ T4 DNA ligase, $3 \mu \mathrm{L}$ ligation buffer, $3 \mu \mathrm{L}$ pTZ57R/T vector (Fermentas), $3 \mu \mathrm{L}$ of PEG 4000 and $4 \mu \mathrm{L}$ amplified DNA in $1.2 \mathrm{~mL}$ tube. Ligation was performed overnight in water bath at

$16{ }^{\circ} \mathrm{C}$. Plasmid isolation of recombinant transformants was performed using Promega mini prep kit.

Cloned PCR products were sequenced on ABI Prism 3100 Genetic Analyser (Hitachi, Japan) using Big Dye Terminator v 1.1 Cycle Sequencing Kit. The gene sequences were compared with others in the GenBank databases using the NCBI BLAST at. http://www.ncbi.n1m.nih.gov/blast/Blast.cgi.

\section{RESULTS}

\section{Virulence of $R$. solani}

$R$. solani was purified by sub-culturing. $R$. solani inoculated plants showed potato black scurf symptoms severely i.e., brown lesions were developed at the base of stem, leaf 
chlorosis and black spots (sclerotia) at tuber surface were also observed both in vivo and in vitro after one week (data not shown). So fungal culture was highly pathogenic to plant.

\section{Primary selection of antagonists}

A total of twenty-eight bacterial strains were isolated on the basis of colony morphology from rhizosphere and associated sites i.e., roots, soil and tubers.

Dual culture assay: There was no physical contact between any of the antagonists and pathogen. An inhibitory halo was observed suggesting the presence of fungistatic metabolites secreted by the bacteria. Microscopic observation of fungal zone showed the cytoplasmic leakage at the hyphal septum. There was a significant difference between bacterial treatments to the \% inhibition of fungal radii. Bacterial strains significantly reduced pathogen growth in comparison to the control. Strains StS3 and StT2 with \% inhibition of 44.3 and 41.7, respectively, were the most effective ones against $R$. solani (Fig. 1). There was no considerable growth of $R$. solani where T. harzianum was used as biocontrol agent (positive control), even disintegration of pathogen was observed. Percentage inhibition of $R$. solani by different bacterial isolates is presented in Fig. 2. Efficient antagonistic bacteria i.e., StS3, StT2, StHR2, StRh2 and StS1y were selected for further studies on the basis of this test.

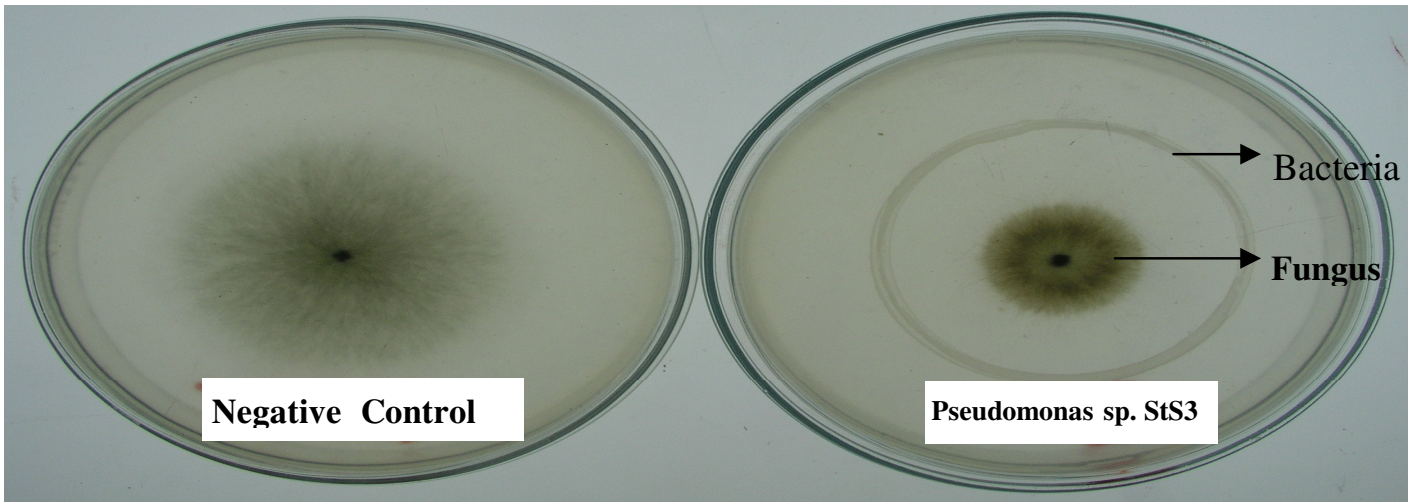

Figure 1. In vitro inhibition assay by "Dual Culture method" showing the antifungal activity of potato rhizosphere associated Pseudomonas sp. StS3 against $R$. solani, the causal agent of potato black scurf disease. Dual inoculation of $R$. solani and bacterial isolate on the same plate containing PDA. Growth of pathogen, $R$. solani (center) was inhibited by Pseudomonas sp. StS3. In negative control, LB broth was used instead of bacterial suspension inoculum.

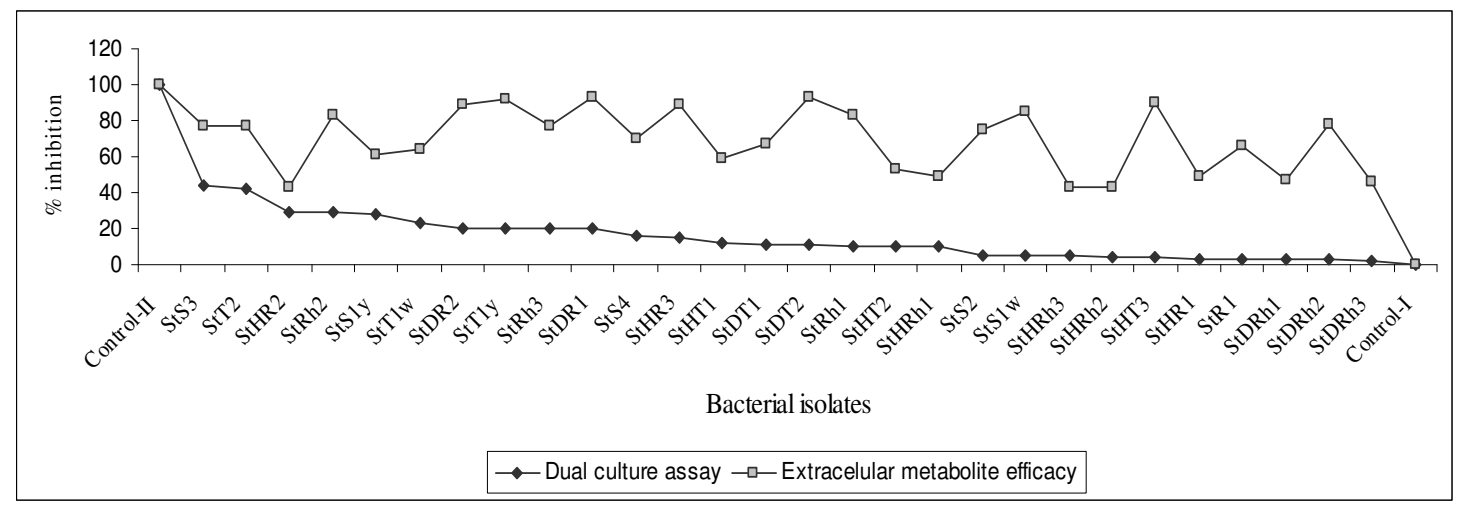

Figure 2. Comparison of "Extra cellular metabolite efficacy test" and "Dual culture assay" to study the antifungal activity of potato rhizosphere associated bacterial isolates against $R$. solani, the causal agent of potato black scurf disease. $R$. solani growth inhibition by bacterial isolates in the "Extracellular metabolite efficacy test" has higher values of inhibition as compared to those of "Dual culture assay". Control -I = Distilled water (negative control), Control -II = Trichoderma harzianum (positive control) 
Extracellular metabolites efficacy test: Pathogen could not grow well in the presence of bacterial extracellular metabolites. There was a significant difference between the bacterial treatments to \% inhibition of fungal radii. Growth of $R$. solani was significantly inhibited by the by antagonistic bacteria tested. Isolates StT1y, StDT2 and StDR1 were the most efficient with 92.3, 93.3 and $93.3 \%$ inhibition of fungal radii, respectively. Percentage inhibition of $R$. solani by different bacterial isolates is presented in Fig. 2. Antagonistic bacteria i.e., StT1y, StDT2, StDR1 and StHT3 were selected on the basis of this test.

\section{Tentative identification of antagonists}

Out of twenty-eight isolated bacterial strains, nine bacterial isolates were screened for further experimentation on the basis of showing pathogen inhibition in dual culture assay and extracellular metabolite efficacy test. Gram staining and light microscopic studies showed that all bacteria were motile and may belong to different genera, mostly Pseudomonas and Bacillus. All bacterial stains were able to grow on King's B agar plates. Bacterial isolates, StS3 and StT2 produced yellow pigmentation on King's B agar plates, may belong to genus Pseudomonas (Table. 1).

Table 1. Morphological and physiological characterization of potato rhizosphere associated antagonistic bacteria.

\begin{tabular}{|c|c|c|c|c|c|c|}
\hline Strain & Origin & $\begin{array}{l}\text { Gram } \\
\text { reaction }\end{array}$ & Colony and cell morphology & $\begin{array}{l}\text { IAA } \\
\text { Production } \\
(\mu \mathrm{g} / \mathrm{mL})\end{array}$ & $\begin{array}{l}\text { Phosphate } \\
\text { solubilization } \\
(\mu \mathrm{g} / \mathrm{mL})\end{array}$ & $\begin{array}{l}\text { Siderophore } \\
\text { production } \\
(\mu \mathrm{g} / \mathrm{mL})\end{array}$ \\
\hline StT1y & $\begin{array}{l}\text { Tuber, } \\
\text { diseased plant. }\end{array}$ & + & $\begin{array}{l}\text { Round large, smooth, dark creamy } \\
\text { colony, round cells }\end{array}$ & - & - & 0.83 \\
\hline StT2 & $\begin{array}{l}\text { Tuber, } \\
\text { diseased plant. }\end{array}$ & - & $\begin{array}{l}\text { Round small, smooth, creamy } \\
\text { colony and short rod }\end{array}$ & - & - & 6.12 \\
\hline StDT2 & $\begin{array}{l}\text { Tuber, } \\
\text { deseased plant. }\end{array}$ & - & $\begin{array}{l}\text { Large round, smooth, creamy } \\
\text { colony and short rod }\end{array}$ & - & - & - \\
\hline StHT3 & $\begin{array}{l}\text { Tuber, } \\
\text { Healthy plant. }\end{array}$ & + & $\begin{array}{l}\text { Round medium, smooth, brownish } \\
\text { creamy colony and long rod }\end{array}$ & - & - & 3.68 \\
\hline StRh2 & $\begin{array}{l}\text { Rhizosphere, } \\
\text { diseased plant. }\end{array}$ & + & $\begin{array}{l}\text { Round small, smooth, creamy } \\
\text { colony and Short rod }\end{array}$ & 31.08 & - & - \\
\hline StS1y & $\begin{array}{l}\text { Soil, } \\
\text { diseased plant. }\end{array}$ & + & $\begin{array}{l}\text { Round large, wavy, dark creamy } \\
\text { colony and Short rod }\end{array}$ & - & - & - \\
\hline StS3 & $\begin{array}{l}\text { Soil, } \\
\text { diseased plant. }\end{array}$ & - & $\begin{array}{l}\text { Round small, smooth, creamy } \\
\text { colony and short rod }\end{array}$ & 0.38 & 18.6 & 3.76 \\
\hline StDR1 & $\begin{array}{l}\text { Root endophyte, } \\
\text { diseased plant. }\end{array}$ & + & $\begin{array}{l}\text { Round medium, wavy, dark } \\
\text { creamy colony and short rod }\end{array}$ & 1.52 & - & - \\
\hline StHR2 & $\begin{array}{l}\text { Root endophyte, } \\
\text { healthy plant. }\end{array}$ & + & $\begin{array}{l}\text { Round medium, smooth, light } \\
\text { yellow and long rod }\end{array}$ & 0.59 & - & - \\
\hline
\end{tabular}

\section{Mechanisms of antagonism}

Volatile antibiotics: Growth of $R$. solani was significantly inhibited by antagonistic bacteria to be tested. Volatile antibiotics produced by bacterial strain StS3 significantly inhibited $23.7 \%$ growth of fungal pathogens. Antagonists i.e., StT2, StS1y and StT1y were also able to suppressed pathogen growth, although all other bacteria showed minor inhibitory effect on $R$. solani growth (Table. 2). 
Table 2. Percent inhibition of $R$. solani growth by volatile and diffusible antibiotics produced by potato rhizosphere associated antagonistic bacteria.

\begin{tabular}{ccc}
\hline Treatment & $\begin{array}{c}\text { Volatile antibiotic } \\
\text { (\% inhibition) }\end{array}$ & $\begin{array}{c}\text { Diffusible antibiotics } \\
\text { (\% inhibition) }\end{array}$ \\
\hline control-II & $31.3 \mathrm{a}$ & $32.0 \mathrm{a}$ \\
StS3 & $23.7 \mathrm{~b}$ & $17.3 \mathrm{c}$ \\
StT2 & $18.3 \mathrm{c}$ & $24.0 \mathrm{~b}$ \\
StS1y & $16.7 \mathrm{c}$ & $16.7 \mathrm{c}$ \\
StRh2 & $13.7 \mathrm{~d}$ & $12.7 \mathrm{~d}$ \\
StT1y & $10.7 \mathrm{e}$ & $10.7 \mathrm{~d}$ \\
StHT3 & $6.3 \mathrm{f}$ & $12.7 \mathrm{~d}$ \\
StHR2 & $5.7 \mathrm{f}$ & $6.3 \mathrm{e}$ \\
StDT2 & $5.0 \mathrm{f}$ & $3.7 \mathrm{f}$ \\
StDR1 & $4.7 \mathrm{f}$ & $4.3 \mathrm{ef}$ \\
Control-I & $0 \mathrm{~g}$ & $3.7 \mathrm{f}$ \\
\hline
\end{tabular}

Different letters in column represents significant difference in Duncan's Multiple Range Test $(\mathrm{p} \leq 0.05)$.

Control $-\mathrm{I}=$ Distilled water (negative control)

Control $-\mathrm{II}=$ Trichoderma harzianum (positive control)

Diffusible antibiotics: Effect of diffusible antibiotic was similar to that of volatile antibiotic. $R$. solani was inhibited independently by each of bacterial strain at varying level (Table. 2). Strain StT2 was the antagonistic bacterial isolate that showed significant inhibitory effect on the growth of $R$. solani isolate tested with $24 \%$ inhibition. Strains StS1y, StS3 and StHT3 were also able to significantly suppressed pathogen growth, although all other bacteria showed minor inhibitory effect on $R$. solani growth.

Siderophores: There was no significant difference between the percentage inhibition of $R$. solani radius at different levels of $\mathrm{Fe}^{+3}$ concentrations tested by any antagonistic strains (Fig. 3). Four antagonistic strains were siderophore positive on CAS agar (Table 1).

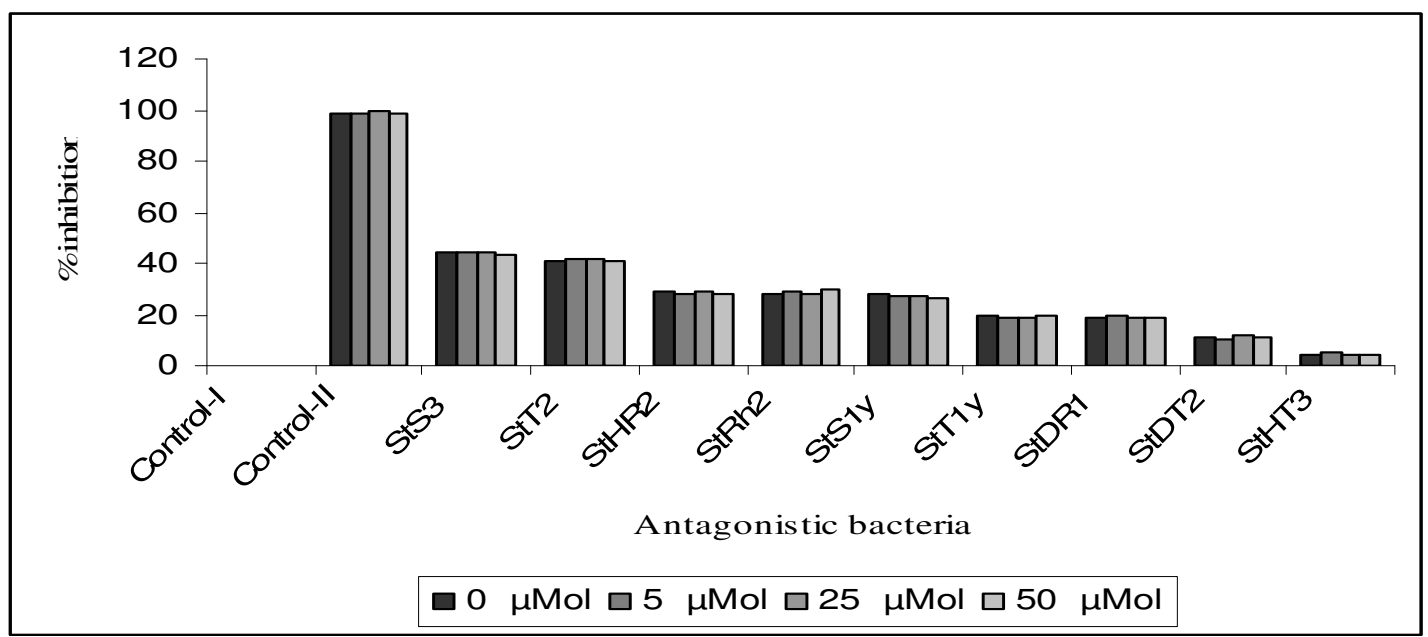

Figure 3. Effect of $\mathrm{Fe}^{+3}$ level of medium on antifungal activity of potato rhizosphere associated bacterial isolates against $R$. solani, the causal agent of potato black scurf disease. Graph represents that $R$. solani growth inhibition is not significantly different at varying concentrations of $\mathrm{FeCl}_{3}$ amended medium i.e. King's B medium for each antagonist. Control $-\mathrm{I}=$ Distilled water (negative control), Control $-\mathrm{II}=$ Trichoderma harzianum (positive control) 
Lytic enzymes: None of these bacteria were able to grow in solid or in liquid media that contained chitin as the sole carbon source. There was no halo formation around the bacteria on skim milk agar plates. Chitinase and protease activity was not detected in any of the bacteria tested (19).

\section{Growth promoting characteristics of bioantagonists}

None of the antagonistic bacteria showed nitrogenase activity in acetylene reduction assay. Four antagonistic strains showed pink coloration in calorimetric method indicating IAA production. IAA produced by four different bacterial isolates ranged from $0.38-31.08 \mu \mathrm{g} / \mathrm{mL}$. StRh2 produced significantly high amount of IAA i.e., $31.08 \mu \mathrm{g} / \mathrm{mL}$. None of bacterial strain showed phosphate solubilizing ability except StS3. Antagonistic strain StS3 was able to solubilize inorganic phosphate at the rate of $18.6 \mu \mathrm{g} / \mathrm{mL}$ (Table 1).

\section{Pot experiment}

The average disease incidence and biocontrol efficacy percentage was determined (Table 3). Negative control (LB broth in infected soil) showed disease incidences 40.7 and its biocontrol efficacy percentage was supposed as zero. There was a significant difference between bacterial treatments to control the disease. Positive control (T. harzianum) showed $67.9 \%$ biocontrol efficacy, while bacterial isolates StT2 and StS3 significantly inhibited $R$. solani with $65.1 \%$ and $73.8 \%$ biocontrol efficacy, respectively.

The average yield and percent yield increase was determined (Table 3). There was a significant difference between bacterial treatments to increase yield percentage of potato tuber. Tuber yield of negative control was $0.27 \mathrm{~kg} /$ plant. Positive control yielded $0.52 \mathrm{~kg} /$ plant while bacterial isolates StT2 and StS3 showed best results by yielding 0.5 $\mathrm{kg} /$ plant and $0.53 \mathrm{~kg} /$ plant, respectively. Percent yield increase of most antagonistic bacteria i.e., StT2 and StS3 was 87.3 and 98.3 respectively.

\section{S rRNA gene amplification and sequencing}

Potent antagonistic strain StS3 was identified using 16S rRNA gene sequencing. The sequence obtained was compared with databank at NCBI BLAST and showed highest similarity i.e., 95\% (615/644), with Pseudomonas putida (accession number $\underline{\mathrm{AB} 029257)}$. The sequence was submitted in NCBI GenBank under the accession number DQ911367.

Table 3. Efficacy of potato rhizosphere associated antagonistic bacteria to enhance potato yield and biocontrol of Rhizoctonia solani, the causal agent of potato black scurf disease in greenhouse.

\begin{tabular}{ccccc}
\hline Strains & Disease incidence & $\begin{array}{c}\text { Biocontrol } \\
\text { efficacy }(\%)\end{array}$ & $\begin{array}{c}\text { Actual Yield } \\
(\mathbf{k g} / \mathbf{p l a n t})\end{array}$ & $\begin{array}{c}\text { Yield increase } \\
(\boldsymbol{\%})\end{array}$ \\
\hline $\mathrm{StS3}$ & $10.3 \mathrm{f}$ & $73.9 \mathrm{a}$ & $0.53 \mathrm{a}$ & $98.3 \mathrm{a}$ \\
$\mathrm{StT} 2$ & $14.0 \mathrm{f}$ & $65.1 \mathrm{a}$ & $0.50 \mathrm{a}$ & $87.3 \mathrm{a}$ \\
StRh2 & $23.0 \mathrm{e}$ & $43.1 \mathrm{~b}$ & $0.41 \mathrm{~b}$ & $54.0 \mathrm{~b}$ \\
StT1y & $25.7 \mathrm{de}$ & $36.1 \mathrm{bc}$ & $0.40 \mathrm{~b}$ & $50.2 \mathrm{bc}$ \\
StS1y & $25.0 \mathrm{de}$ & $38.0 \mathrm{bc}$ & $0.38 \mathrm{bc}$ & $42.0 \mathrm{bc}$ \\
StHT3 & $29.7 \mathrm{~cd}$ & $26.6 \mathrm{~cd}$ & $0.35 \mathrm{~cd}$ & $32.1 \mathrm{bcd}$ \\
StHR2 & $32.7 \mathrm{bc}$ & $18.5 \mathrm{~d}$ & $0.33 \mathrm{de}$ & $23.8 \mathrm{cde}$ \\
StDT2 & $36.0 \mathrm{ab}$ & $10.7 \mathrm{de}$ & $0.30 \mathrm{ef}$ & $12.8 \mathrm{de}$ \\
StDR1 & $40.0 \mathrm{a}$ & $0.4 \mathrm{e}$ & $0.30 \mathrm{ef}$ & $11.2 \mathrm{de}$ \\
control-II & $13.0 \mathrm{f}$ & $67.9 \mathrm{a}$ & $0.52 \mathrm{a}$ & $95.2 \mathrm{a}$ \\
control-I & $40.7 \mathrm{a}$ & $0.0 \mathrm{e}$ & $0.27 \mathrm{f}$ & $0.0 \mathrm{e}$ \\
\hline
\end{tabular}

Different letters in column represents significant difference in Duncan's Muultiple Range Test $(\mathrm{p} \leq 0.05)$.

Control $-\mathrm{I}=$ Distilled water (negative control)

Control $-\mathrm{II}=$ Trichoderma harzianum $($ positive control) 


\section{DISCUSSION}

In the present study, rhizosphere associated bacteria were evaluated for their antagonism against $R$. solani, causative agent of potato black scurf. The objective of the study was to select antagonistic bacteria active against $R$. solani in vitro as well as in vivo, and promote plant growth. The study resulted in the primary selection of nine antagonistic bacteria, out of them, two bacterial strains belonging to genus Pseudomonas, StS3 and StT2 significantly promoted plant growth with reduced disease incidence. Production of diffusible and volatile antibiotic was found to be common characteristic among all the potential antagonistic bacterial strains and might be significantly adding its role in antagonism against $R$. solani. Similar findings were reported previously by Montealegre et al. (27).

A total of twenty-eight bacterial strains were isolated from healthy and black scurf infected potato plants collected from different areas of Pakistan. Antagonism of all the twenty-eight bacterial isolates was first evaluated against $R$. solani by in vitro test i.e., dual culture assay and extra-cellular metabolite efficacy test. On the basis of these tests, overall nine efficient antagonistic bacteria i.e., StS3, StT2, StRh2, StT1y, StS1y, StHT3, StHR2, StDT2, StDR1 were selected, which were found to control $R$. solani. These potential biocontrol agents were selected for the study of mechanism of biocontrol and also evaluated for biocontrol efficacy in greenhouse experiment.

Dual culture assay showed that antagonistic strains StT2 and StS3 were most efficient with $41.7 \%$ and $44.3 \%$ pathogen inhibition (5). The pot experiment results were also similar to that of dual culture assay. Therefore, it is concluded that dual culture assay can be used as standard test for the selection of biocontrol agent and shows cumulative effect of all mechanisms undergoing for biocontrol i.e., siderophore production, diffusible and volatile antibiotic production, lytic enzymes production etc $(8,27)$.

Extra-cellular metabolite efficacy test is also thought to be one of the gross level antagonistic tests. Results varied a lot from dual culture assay. StT1y, StDT2 and StDR1 were the most efficient strains in extra-cellular metabolite efficacy test with $92.3 \%, 93.3 \%$ and $93.3 \%$ pathogen inhibition. But the results of pot experiment did not support the results of extracellular metabolite efficacy test. Keeping in view these observations, it is concluded that extra-cellular metabolite efficacy test may not represent cumulative effect of all underlying biocontrol mechanisms.

Rhizosphere associated bacteria have drawn much attention, as they have the ability for root colonization and offensive mechanisms against the pathogen by the production of allelochemicals, including siderophores, lytic enzymes, volatile and diffusible antibiotics $(4,8)$. Among rhizobacteria, genus Pseudomonas is more competitive due to the production of secondary metabolites. Pseudomonads are also reported to be involved in growth promotion by the production of phytohormones, nitrogen fixation, phosphate solubilization (31).

Iron is the essential growth element for all living organisms. Scarcity of bioavailable iron in soil habitat and on plant surface results in a furious competition. Under ironlimiting conditions rhizobacteria produce low-molecularweight compounds called siderophores to competitively acquire ferric ion (48). Although various bacterial siderophores differ in their abilities to sequester iron, in general, they deprive pathogenic fungi of this essential element since the fungal siderophores have lower affinity to chelate iron (24). But this attribute of producing siderophores is beneficial only when iron is limiting factor in soil. In this study, it is seen that antagonism was not affected by different concentrations of iron used. If it is considered that iron available in soil fluctuate from 5-50 ppm, it can be concluded that iron is not limiting factor for the antagonistic activity of bacteria against $R$. solani, so siderophore production is ineffective. Similar results have been declared by Montealegre and Kazempour $(19,27)$.

An important role of hydrolytic enzymes has been well documented as a variety of microorganisms also exhibit hyperparasitic activity, attacking pathogens by excreting these enzymes (7, 35). Pseudomonas and Bacillus spp. normally do 
not produce lytic enzyme except Pseudomonas stutzeri and Bacillus cepacia $(11,22)$. As most of the selected antagonistic strains used were Pseudomonas and Bacillus spp., so none of them showed secretion of lytic enzymes suggesting that enzymes, if synthesized, were not secreted, or that these enzymes were not synthesized at all by the bacteria.

If we consider that none of these bacteria was able to secrete any of the enzymes involved in biocontrol, siderophore ineffective, then some had the ability to control $R$. solani might be through the secretion of diffusible and volatile metabolites. It may be concluded that they use these two latter mechanisms (volatile and diffusible antibiotic production) of biocontrol against fungus in this study (27).

$T$. harzianum is a well known biocontrol agent of $R$. solani was used in this study as positive control. Pseudomonas spp. StS3 and StT2 were found to inhibit $R$. solani to control potato black scurf disease as well as increase yield comparable to that of standard biocontrol agent (T. harzianum). Therefore, these antagonistic strains can be considered as promising bacteria for an alternative biocontrol agent.

Pot experiment results, regarding the selection of potent antagonistic bacteria also supported lab studies. Bacterial strains, StT2 and StS3 were found to be most effective with $65.1 \%$ and $73.9 \%$ biocontrol efficacy. Therefore, antagonistic strains StT2 and StS3 can effectively be used as biocontrol agent. Yield increase percentage of StT2 (87.3\%) and StS3 (98.3\%) was comparable to that of control plants. Among these two antagonistic bacteria, the tuber yield with StS3 was higher than that of StT2. To elucidate this fact, it is supposed that this yield increase percentage with $\mathrm{StS} 3$ might be due to its beneficial growth promoting activities i.e., phosphate solubilization and IAA production. The phosphate solubilizing microorganism can increase the availability of phosphorus to plant by mineralizing organic phosphorus compound and by converting inorganic phosphorus into more available form (31, $50)$.

16S rRNA gene sequence revealed that best antagonistic strain StS3 is Pseudomonas sp. Gasoni et al. (12) have already reported in 1998 that Pseudomonas spp. are well known biocontrol agent of $R$. solani, so this study gave another evidence that Pseudomonas spp. are efficient biocontrol agent $(2,31)$.

In the present study, we for the first time report Pseudomonas sp. StS3 as an effective biocontrol agent of potato black scurf with the production of diffusible and volatile antibiotics, siderophore, IAA and phosphate solubilization. On the basis of above mentioned results, it is concluded that Pseudomonas sp. StS3 can be used under field conditions as an effective biocontrol agent promoting plant growth with reduced disease incidence.

\section{ACKNOWLEDGEMENT}

The authors would like to thank Dr. M. Sajjad Mirza (Principle Scientist, NIBGE) for his help in DNA sequencing. We are also grateful to Dr. Zakira Nureen for her intellectual inputs and Ms Aisha Naeem (Lecturer CIIT, Islamabad) for her help in submission of this manuscript. This work was partially supported by Higher Education Commission (HEC) Research Grant No. 544.

\section{REFERENCES}

1. Almeida, F.B.R.; Cerqueira, F.M.; Silva, R.N.; Ulhoa, C.J.; Lima, A.L. (2007). Mycoparasitism studies of Trichoderma harzianum strains against Rhizoctonia solani : evaluation of coiling and hydrolytic enzyme production. Biotechnol. Lett. 29 (8), 1189-1193.

2. Altindag, M.; Sahin, M.; Esitken, A.; Ercisli, S.; Guleryuz, M.; Donmez, M.F.; Sahin, F. (2006). Biological control of brown rot (Moniliana laxa Ehr.) on apricot (Prunus armeniaca L. cv. Hacıhaliloğlu) by Bacillus, Burkholdria, and Pseudomonas application under in vitro and in vivo conditions. Biol. Control. 38 (3), 369-372.

3. Baker, K.; Cook, R. (1974). Biological control of plant pathogens. W.H. Freeman Company, San Francisco, USA, p. 433.

4. Bais, H.P.; Park, S.W.; Weir, T.L.; Callaway, R.M.; Vivanco, J.M. (2004). How plants communicate using the underground information superhighway. Trends Plant Sci. 9 (1), 26-32.

5. Berg, G.; Krechel, A.; Ditz, M.; Sikora, R.A.; Ulrich, A.; Hallmann, J. (2005) Endophytic and ectophytic potato-associated bacterial communities differ in structure and antagonistic function against plant pathogenic fungi. FEMS Microbiol. Ecol. 51, 215-229.

6. Berg, G.; Fritze, A.; Roskot, N.; Smalla, K. (2001). Evaluation of potential biocontrol rhizobacteria from different host plants of Verticillium dahliae Kleb. J. Appl. Microbiol. 91, 963-971. 
7. Chernin, L.; Chet, I. (2002). Microbial enzymes in biocontrol of plant pathogens and pests. In: R. G. Burns and R. P. Dick (ed.), Enzymes in the environment: activity, ecology, and applications. Marcel Dekker, New York, pp. 171-225.

8. Compant, S.; Reiter, B.; Sessitsch, A.; Nowak, J.; Clement, C.; Barka, E.A. (2005a). Endophytic colonization of Vitis vinifera L. by a plant growth-promoting bacterium, Burkholderia sp. strain PsJN. Appl. Environ. Microbiol. 71 (4), 1685-1693.

9. Compant, S.; Duffy, B.; Nowak, J.; Clement, C.; Barka, E.A. (2005b). Use of Plant growth-promoting bacteria for biocontrol of plant diseases: principles, mechanisms of action, and future prospects. Appl. Environ. Microbiol. 71 (9), 4951-4959.

10. Errampalli, D.; Johnston, H.W. (2001). Control of tuber-borne black scurf [Rhizoctonia solani] and common scab [Streptomyces scabies] of potatoes with a combination of sodium hypochlorite and thiophanatemethyl preplanting seed tuber treatment. Can. J. Plant Pathol. 23: 68-77.

11. Fredlender, M.; Inbar, J.; Chet, I. (1993). Biological control of soilborne plant pathogens by a B-1,3-glucanase-producing Pseudomonas cepacia. Soil Biol. Biochem. 25, 1211-1221.

12. Gasoni, L.; Cozzi, J.; Kobayashi, K.; Yossen, V.; Zumelzu, G.; Babbitt, S. (1998). Suppressive effect of antagonistic agents on Rhizoctonia isolates on lettuce and potato in Argentina field plots. In: International Congress of Plant Pathology. (7 ${ }^{\circ}, 9$ th - 16th August, 1998, Edinburgh, Scotland). p. 5.2.44.

13. Gull, M.; Hafeez, F.Y.; Saleem, M.; Malik, K.A. (2004). Phosphateuptake and growth promotion of chickpea (Cicer arietinum L.) by coinoculation of mineral phosphate solubilizing bacteria and a mixed rhizobial culture. Aust. J. Exp. Agri. 44 (6), 623-628.

14. Gull, M. (2008). Biological control of pathogenic infection through plant growth promoting rhizobacteria. Ph. D. dissertation, Quaid-i-Azam University, School of Biotechnology, NIBGE Campus, Pakistan.

15. Grosch, R.; Faltin, F.; Lottmann, J.; Kofoet, A.; Berg, G. (2005). Effectiveness of 3 antagonistic bacterial isolates to control Rhizoctonia solani Kühn on lettuce and potato. Canadian J. Microbiol. 51: 4, pp. 345353(9).

16. Guo, J.H.; Qi, H.Y.; Guo, Y.H.; Ge, H.L.; Gong, L.Y.; Zhang, L.X.; Sun, P.H. (2004). Biocontrol of tomato wilt by plant growth-promoting rhizobacteria. Biol. Control 29 (1), 66-72.

17. Hafeez, F.Y.; Yasmin, S.; Ariani, D.; Rahman, M.; Zafar, Y.; Malik, K.A. (2006). Plant growth-promoting bacteria as biofertilizer. Agron. Sustain. Dev. 26, 143-150.

18. Juan-Abgona, R.V.; Katsuno, N.; Kageyama, K.; Hyakumachi, M. (1996). Isolation and identification of hypovirulent Rhizoctonia spp. From soil. Plant Pathol. 45, 896-904.

19. Kazempour, M.N. (2004). Biological control of Rhizoctonia solani, the causal agent of rice sheath blight by antagonistic bacteria in greenhouse and field conditions. Plant Pathol. J. 3 (2), 88-96.

20. Kiewnick, S.; Sikora, R.A. (2006). Biological control of the root-knot nematode Meloidogyne incognita by Paecilomyces lilacinus strain 251 . Biol. Control 38, 179-187.

21. Lim H.S.; Kim, Y.S.; Kim, S.D. (1991). Pseudomonas stutzeri YPL-1 genetic transformation and antifungal mechanism against Fusarium solani, an agent of plant root rot. Appl. Environ. Microbiol. 57, 510-516.

22. Lin, A.; Lee, T.M.; Rern, J.C. (1994). Tricholin, a new antifungal agent from Trichoderma viride and its action in biological control of Rhizoctonia solani. J. Antibiotics. 47 (7), 799-805.

23. Loper, J.E.; Henkels, M.D. (1997). Availability of iron to Pseudomonas fluorescens in rhizosphere and bulk soil evaluated with an ice nucleation reporter gene. Appl. Environ. Microbiol. 63 (1), 99-105.

24. Lutz, M.P.; Wenger, S.; Maurhofer, M.; Defago, G.; Duffy, B. (2004). Signaling between bacterial and fungal biocontrol agents in a strain mixture. FEMS Microbiol. Ecol. 48, 447-455.

25. Maniatis, T.; Fritsch, E.F.; Sambrook J. (1982). Molecular Cloning: A Laboratory Manual. Cold Spring Harbor Laboratory, U.S.A, p. 545.

26. Montealegre, J.R.; Reyes, R.; Perez, L.M.; Herrera, R.; Silva, P.; Besoain, X. (2003). Selection of bioantagonistic bacteria to be used in biological control of Rhizoctonia solani in tomato. Electronic J. Biotechnol. 6, 115-127.

27. Murphy, J.; Riley, J.P. (1962). Modified solution method for determination of phosphate in natural water. Anal. Chem. Acta. 27, 3136.

28. Nair, A.; Juwarkar, A.; Singh, S. (2007). Production and characterization of siderophores and its application in arsenic removal from contaminated soil. Water, Air, and Soil Pollution 180, pp. 199-212(14).

29. Okon, Y.; Albercht, S.L.; Burris, R.H. (1977). Methods for growing spirillum lipoferum and for counting it in pure culture and in association with plants. Appl. Environ. Microbiol. 33, 85-88.

30. Panday, A.; Trivedi, P.; Kumar, B.; Palni, L.M.S. (2006). Characterization of phosphate solubilizing and antagonistic strain of Pseudomonas putida (BO) Isolated from a sub-alpine location in the Indian Central Himalaya. Current Microbiol. 53, 102-107.

31. Park, M.S.; Jung, S.R.; Lee, M.S.; Kim, K.O.; Do, J.O.; Lee, K.H.; Kim, S.B.; Bae, K.S. (2005). Isolation and characterization of bacteria associated with two sand dune plant species, Calystegia soldanella and Elymus mollis. J. Microbiol. 43 (3), 219-227.

32. Paynter, Q. (2005). Evaluating the impact of the biological control agent Carmenta mimosa on the woody wetland weed Mimosa pigra in Australia. J. Appl. Ecol. 42, 1054-1062.

33. Paynter, Q.; Waipara, N.; Peterson, P.; Hona, S.; Fowler, S.; Gianotti, A.; Wilkie, P. (2006). The impact of two introduced biocontrol agents, Phytomyza vitalbae and Phoma clematidina, on Clematis vitalba in New Zealand. Biol. Control 36, in press.

34. Perez, L.M.; Besoain, X.; Reyes, M.; Pardo, G.; Montealegre, J. (2002). The expression of extracellular fungal cell wall hydrolytic enzymes in different Trichoderma harzianum isolates correlate with their ability to control Pyrenochaeta lycopersici. Biol. Res. 35 (3-4), 401-410. 
35. Peterson, R.G. (1985). Design and analysis of experiments, Marcel Dekker. Inc. New York and Bassel, 429.

36. Pikovskia, R.I. (1948). Metabolisation of phosphorus in soil in connection with vital activity of some microbial species. Microbiologiya $17,362-370$

37. Postma, J.; Montanari, M.; van den Boogert, P.H.J.F. (2003). Microbial enrichment to enhance the disease suppressive activity of compost. Eur. J. Soil Biol. 39, 157-163.

38. Pumarino, A. (1995). Evaluación in vitro del control biológico de la Fusariosis del fréjol. Tesis (Memoria de Título Ingeniería Agraria). Santiago, Chile, Universidad de Chile, Facultad de Ciencias Agrarias y Forestales, p. 70.

39. Rachid, D.; Bensoltane, A. (2005) Effect of iron and growth inhibitors on siderophores production by Pseudomonas fluorescens. Afr. J. Biotechnol. 4 (7) 697-702

40. Raupach, G.S.; Kloepper, J.W. (1998). Mixtures of plants growthpromoting rhizobacteria enhance biological control of multiple cucumber pathogens. Phytopathol. 88 (11), 1158-1164.

41. Sabuquillo, P.; Cal, A.D.; Melgarejo, P. (2006). Biocontrol of tomato wilt by Penicillium oxalicum formulations in different crop conditions. Biol. Control 37, 256-265.

42. Schwyn, B.; Neilands, J.B. (1987). Universal chemical assay for detection and determination of siderophores. Anal. Biochem. 160, 40-47.

43. Sharma, A.; Johri, B.N. (2003). Growth promoting influence of siderophore-producing Pseudomonas strains GRP3 and PRS9 in maize (Zea mays L.) under iron limiting conditions. Microbiol. Res. 158 (3), 243-248.
44. Sikora, R.A.; Fernandez, E. (2005). Nematode parasites of vegetables. In: Luc, M., Sikora, R.A., Bridge, J. (Eds.), Plant-parasitic nematodes in subtropical and tropical agriculture, second ed. CABI Publishing, Wallingford, UK, pp. 319-392.

45. Tan, Z.; Xu, X.; Wang, E.; Gao, J.; Martinez-Romero, E.; Chen, W. (1997). Phylogenetic and genetic relationships of Mesorhizobium tianshanense and related rhizobia. International J. Systematic Bacteriol. 47 (3), 874-879.

46. Todaz, K. (2005). Pseudomonas and related bacteria. University of Wisconsin-Madison Department of Bacteriology. Todar's Online Textbook of Bacteriology.

47. Vincent, J.M. (1970). A manual for the practical study of root nodule bacteria. IBP Handbook, Blackwell Oxford. 15.

48. Whipps, J.M. (2001). Microbial interactions and biocontrol in the rhizosphere. J. Exp. Bot. 52, 487-511.

49. Wick, T.; Hall, B.; Thurn, R. (2001). Rhizoctonia or black scurf on potato. South Australion Research \& Development Institute., Plant Research Centre, Hartley Grove, Urrbrae South Australia 5064.

50. Yasmin, S.; Bakar, M.A.R.; Malik, K.A.; Hafeez, F.Y. (2004). Isolation, characterization and beneficial effects of rice associated plant growth promoting bacteria from Zanzibar soils. J. Basic Microbiol. 44 (3), 241252.

51. Zaldivar, M.; Velásquez, J.C.; Contreras, I.; Perez, L.M. (2001). Trichoderma aureoviride 7-121, a mutant with enhanced production of lytic enzymes: its potential use in waste cellulose degradation and/or biocontrol. Electronic J. Biotechnol. 4 (3), 160-168. 